\title{
Militarização e Escola Sem Partido: duas faces de um mesmo projeto
}

\section{Militarization and non-partisan school} double-sided project

\section{Militarización y escuela sin partido: dos faces de un mismo proyecto}

\author{
CATARINA DE ALMEIDA SANTOS* \\ Universidade de Brasília, Brasília- DF, Brasil. \\ RODRIGO DA SILVA PEREIRA* \\ Universidade Federal da Bahia, Salvador- BA, Brasil.
}

\begin{abstract}
RESUMO: Oartigo debate o processo de militarização das escolas públicas brasileiras e o movimento/projeto "escola sem partido", apontando que ambos fazem parte de um projeto hegemônico e conservador que coloca em risco direitos fundamentais e preceitos constitucionais, dentre eles, os direitos sociais e, mais especificamente, o direito à educação e seus princípios, como definidos e defendidos na Constituição Federal de 1988 e na atual Lei de Diretrizes Bases de Educação Nacional.

Palauras-chave: Militarização das escolas públicas. Escola Sem Partido. Direito à educação.
\end{abstract}

\begin{abstract}
The article discusses the process of militarization of Brazilian public schools and the "non-partisan school" movement / project, pointing out that both are part of a hegemonic and conservative project that puts at risk fundamental rights and constitutional precepts, among them, social rights and, more specifically, the right to
\end{abstract}

* Doutora em Educação pela Universidade de São Paulo e mestra também em Educação pela Universidade Federal de Goiás. Atualmente é professora adjunta da Faculdade de Educação da Universidade de Brasília. Compõe o Comitê Editorial da Revista Retratos da Escola. E-mail: <cdealmeidasantos@gmail.com>.

* Doutor e mestre em Políticas Públicas e Gestão da Educação pelo Programa de Pós-Graduação da Faculdade de Educação da Universidade de Brasília. É professor adjunto I na Faculdade de Educação da Universidade Federal da Bahia. E-mail: <rodrigosilvapereira@ufba.br>. 
education and its principles, as defined and defended by the Federal Constitution of 1988 and in the current Law of Directives and Basis for National Education (LDB).

Keywords: Militarization of public schools. Non-partisan school. Right to education.

RESUMEN: El artículo debate sobre el proceso de militarización de las escuelas públicas brasileñas y el movimiento/proyecto "escuela sin partido", discutiendo que ambos forman parte de un proyecto hegemónico y conservador que pone en riesgo derechos fundamentales y preceptos constitucionales, entre ellos los derechos sociales, y más específicamente el derecho a la educación y sus principios, como definidos y defendidos en la Constitución Federal de 1988 y en la actual Ley de Directrices y Bases de la Educación Nacional.

Palabras clave: Militarización de las escuelas públicas. Escuela sin Partido. Derecho a la educación.

\section{Introdução}

Constituição de 1988 é, sem dúvida, um marco no processo de redemocrati-
zação do Brasil, após mais de duas décadas de ditadura militar (1964-1985),
período que foi demarcado por censura, perseguição política, supressão de direitos constitucionais e a repressão àqueles que eram contrários ao Regime. A ditadura foi instalada após a deposição do então presidente João Goulart, que havia sido eleito vice-presidente pelo Partido Trabalhista Brasileiro (PTB) e a tomada do poder pelo Marechal Castelo Branco, sob a alegação de que havia uma ameaça comunista no País.

Se os chamados anos de chumbo foram demarcados pelo cerceamento de direitos fundamentais, como a liberdade de expressão e de organização, com supressão e interferências nos partidos políticos, sindicatos, agremiações estudantis e outras organizações representativas da sociedade, foram também anos de muita luta pelo reestabelecimento desses direitos.

As eleições de Tancredo Neves e a sua morte, que levou o seu vice, José Sarney ao poder, pôs fim a 21 anos de regime de repressão e deu início a um intenso debate sobre a necessidade de convocação de uma Assembleia Constituinte, de modo a reestabelecer a democracia no País. A Constituinte foi instalada no Congresso Nacional, em Brasília, no dia $1^{\circ}$ de fevereiro de 1987 com a finalidade de elaborar uma Constituição democrática para o Brasil. 
A Carta Magna de 1988, também conhecida como Constituição Cidadã, foi aprovada pela Assembleia Nacional Constituinte no dia 22 de setembro de 1988 e promulgada em 5 de outubro desse ano, trazendo no seu Art. 1ํ que o Brasil é um Estado Democrático de Direito e tem como fundamentos, a soberania; a cidadania; a dignidade da pessoa humana; os valores sociais do trabalho e da livre iniciativa e; o pluralismo político, objetivando, de acordo com seu Art. $3^{0}$ a construção de uma sociedade livre, justa e solidária (BRASIL, 1988).

Como condição para construção dessa sociedade justa e solidária, a nossa lei maior traz um conjunto de direitos sociais, considerados fundamentais para a vida e a dignidade de todos os brasileiros e aqueles que residem no País. Assim, o Art. $6^{\circ}$ define que "são direitos sociais a educação, a saúde, a alimentação, o trabalho, a moradia, o transporte, o lazer, a segurança, a previdência social, a proteção à maternidade e à infância, a assistência aos desamparados" e, no caso específico da educação, estabelece, ainda, os princípios que devem regê-la e as condições para garanti-la.

A sociedade brasileira vem, nesses 30 anos da promulgação da Constituição de 1988, lutando para que esses direitos sejam efetivamente garantidos, em um país que, como apontava Anísio Teixeira, não é só demarcado pela sua geografia de dimensões continentais. A luta é por garantia dos direitos sociais em um Brasil de distâncias físicas, materiais, sociais, culturais, econômicas e raciais. Assim, o presente artigo objetiva debater o processo de militarização das escolas públicas brasileiras e o movimento/projeto escola sem partido, tendo em vista que esses processos fazem parte de um projeto hegemônico e conservador e colocam em risco a permanência dos direitos fundamentais e dos preceitos constitucionais, dentre eles, o direito à educação, como definida e defendida na Carta Magna.

Este trabalho está dividido em quatro seções, além desta introdução. A seguinte seção discute a militarização, em seguida o projeto/movimento ESP e, por fim, apresenta breves considerações.

\section{Militarização das escolas públicas e violação dos princípios constitucionais}

Em 1947, ao debater com os deputados da Assembleia Constituinte Baiana, sobre o Capítulo de Educação e Cultura, Anísio Teixeira, que era, na ocasião, secretário de Educação e Saúde do Estado, falou sobre a importância da educação e a defendeu como um direito, pois para ele não havia nada que se sobrepunha à importância da educação, tendo em vista ser ela o meio para a construção da democracia, para minoração das desigualdades e alcance da justiça social. Democracia é, segundo Teixeira (2002) "um regime de saber e de virtude. E saber e virtude não chegam conosco ao berço, mas são aquisições lentas e penosas (...)" que se alcançam com processos organizados, por meio da educação. Diz o autor 


\begin{abstract}
Democracia é, literalmente, educação. Há, entre os dois termos, uma relação de causa e efeito. Numa democracia, pois, nenhuma obra supera a de educação. Haverá, talvez, outras aparentemente mais urgentes ou imediatas, mas estas mesmas pressupõem, se estivermos numa democracia, a educação. Com efeito todas as demais funções do Estado democrático pressupõem a educação. Somente esta não é a consequência da democracia, mas a sua base, o seu fundamento, a condição mesma para a sua existência (TEIXEIRA, 2002, p. 34).
\end{abstract}

Passados 41 anos desse discurso de Anísio Teixeira, a CF de 1988, que demarca o processo de abertura política pós-regime militar, define no seu Art. $3^{\circ}$ que constituem objetivos fundamentais da República Federativa do Brasil, dentre outros, a construção de uma sociedade livre, justa e solidária e o combate a toda e qualquer forma de discriminação. Ao tratar dos direitos e garantias fundamentais, estabelece no Art. $5^{\circ}$ que todos são iguais perante a lei e que será garantido aos brasileiros e aos estrangeiros residentes no País a inviolabilidade do direito à vida, à liberdade, à igualdade, à segurança e à propriedade. Ao definir os direitos sociais, coloca a educação como o primeiro desses direitos, tendo em vista ser, este, fundamental para o alcance dos demais.

Ao definir a educação como direito social de todos, inclusive dos que não tiveram acesso na idade adequada, a CF 1988 definiu também de quem seria a responsabilidade pela garantia deste direito. Assim, o Art. 205, define que o dever de garantir o direito à educação é do Estado e da família, que deverá promovê-la e incentivá-la, com a colaboração da sociedade. Define, ainda, que a educação a ser ofertada objetiva o "pleno desenvolvimento da pessoa, seu preparo para o exercício da cidadania e sua qualificação para o trabalho" (BRASIL, 1988).

A Carta Magna estabeleceu, ainda, um conjunto de princípios que devem basear a oferta da educação no País, de modo que todo cidadão tenha garantido seu pleno desenvolvimento como pessoa, esteja preparado para o exercício da cidadania e qualificado para o trabalho. Nesse sentido o Art. 206 define que o ensino será ministrado com base nos seguintes princípios:

I - igualdade de condições para o acesso e permanência na escola;

II - liberdade de aprender, ensinar, pesquisar e divulgar o pensamento, a arte e o saber;

III - pluralismo de ideias e de concepções pedagógicas, e coexistência de instituições públicas e privadas de ensino;

IV - gratuidade do ensino público em estabelecimentos oficiais;

V - valorização dos profissionais da educação escolar, garantidos, na forma da lei, planos de carreira, com ingresso exclusivamente por concurso público de provas e títulos, aos das redes públicas;

VI - gestão democrática do ensino público, na forma da lei;

VII - garantia de padrão de qualidade.

VIII - piso salarial profissional nacional para os profissionais da educação escolar pública, nos termos de lei federal. (BRASIL, 1988) 
A retomada, aqui, dos princípios constitucionais é fundamental para a discussão da temática deste artigo, tendo em vista a necessidade de problematização dos dois temas nele debatidos. É importante questionar em que medida os retrocessos impostos nos processos educativos, por meio da militarização das escolas públicas e das imposições propostas pelo movimento/projeto "Escola sem Partido", não inviabilizam a garantia do direito à educação e ferem os princípios que devem regê-la.

Um projeto educativo que garanta a consecução dos objetivos da educação, como previsto na CF de 1988, requer que na sua construção e implementação sejam respeitados os princípios basilares já citados. Em um Estado Democrático de Direito, a educação, como aponta Anísio Teixeira (2002), é pedra fundamental. Para ele, “a democracia é, assim, o regime em que a educação é o supremo dever, a suprema função do Estado". Segundo o autor

[...] ]embora todos os regimes dependam da educação, a democracia depende da mais difícil das educações e da maior quantidade de educação. Há educação e educação. Há educação que é treino, que é domesticação. E há educação que é formação do homem livre e sadio. Há educação para alguns, há educação para muitos e há educação para todos. A democracia é o regime da mais difícil das educações, a educação pela qual o homem, todos os homens e todas as mulheres aprendem a ser livres, bons e capazes (TEIXEIRA, 2002, p. 34).

A luta pela construção de um país livre, com justiça social e ideais de liberdade, desencadeou na aprovação, tanto na Constituição como na Lei de Diretrizes e Bases da Educação Nacional (LDB 9.394/1996), que a educação deve ser inspirada e regida, dentre outros, pelos princípios de liberdade, pluralismo de ideias e concepções pedagógicas, gestão democrática e qualidade.

A LDB, ao dispor sobre a organização da educação, define, no Art. 14, que "os sistemas de ensino definirão as normas da gestão democrática do ensino público na educação básica, de acordo com as suas peculiaridades" (BRASIL, 1996), e ressalta, nos incisos I e II, que nessa definição deve ser garantida a "participação dos profissionais da educação na elaboração do projeto pedagógico da escola; e a participação das comunidades escolar e local em conselhos escolares ou equivalentes" (BRASIL, 1996).

Na contramão dos princípios e diretrizes das leis nacionais, muitos estados brasileiros têm contrariado os preceitos legais e transferido a gestão das instituições escolares sob a responsabilidade dos seus sistemas de ensino para a Polícia Militar. Ao fazer isso, ferem, por exemplo, o princípio da gestão democrática e desconsideram o Art. 15 da LDB, que define que os sistemas de ensino devem assegurar às unidades escolares públicas de educação básica sob sua jurisdição "progressivos graus de autonomia pedagógica e administrativa e de gestão financeira, observadas as normas gerais de direito financeiro público" (BRASIL, 1996). Vejam, por exemplo, trecho do Regimento Interno dos Colégios da Polícia Militar do Estado de Goiás, que, embora reconheça a possibilidade de Associações de Pais e Mestres, condiciona que: 
Art. 69. Uma vez eleita a nova diretoria, esta deverá ser submetida à apreciação para homologação pelo Comando e Direção do CPMG.

$\S 1$ o Em caso de inobservância das prescrições desta seção, o CPMG não reconhecerá a legitimidade representativa da ASPM e será dissolvida por ato do Comandante e Diretor.

Ou seja, mesmo eleitas em assembleia, as ASPM estão subsumidas ao Diretor-Comandante da PM, podendo ele, se julgar necessário, dissolver a diretoria. Essa normativa e procedimento também se aplica aos grêmios estudantis, que, segundo regimento, deverão ter em sua composição "representantes de pais e professores". Se não observada tal determinação, a entidade estudantil não será reconhecida pelo alto comando.

De acordo como § 5을 do art. 144 da CF de 1988, a função das polícias no Brasil é garantir segurança pública, cabendo às polícias militares, em específico, a polícia ostensiva e a preservação da ordem pública. Assim, colocar a gestão das escolas públicas não pertencentes às corporações, sob a responsabilidade dos militares, além de se constituir claro desvio de função, é negar os princípios e finalidades da educação nacional, na medida em que os processos organizativos e pedagógicos dessas escolas deixam de seguir a LDB e são definidos pelas normas das corporações.

O processo de militarização das escolas no Brasil tem seu ápice no estado de Goiás, que atualmente conta com 46 escolas, sob a gestão da Polícia Militar e com 53 mil alunos estudando sob regime de quartel. O Art. $1^{1}$ do regimento interno das escolas públicas sob a gestão da PM em Goiás define claramente que as escolas em questão estão subordinadas à Secretaria da Segurança Pública, por meio da Polícia Militar do Estado de Goiás e da Unidade Gestora de Grande Comando, tendo a Secretaria Estadual de Educação apenas como parceira, por meio do Termo de Cooperação Técnico pedagógico.

Esse modelo, no entanto, já não se restringe a Goiás, e vem rapidamente se espalhando pelo País. Em fala para empresários e políticos, no evento promovido pela Lide-Bahia (Grupo de Líderes Empresariais), que aconteceu em Salvador, no dia 17 de novembro de 2015, Marconi Perillo, então governador de Goiás, afirmou que "Muita gente está de olho no que vamos fazer lá, pessoas focadas na melhoria da educação, pois todos querem ver essa área avançar". ${ }^{1}$

As razões e motivações apontadas por Marconi Perillo, quatro vezes governador de Goiás, idealizador desse projeto e responsável pela militarização no estado, mostram que não só a democracia está em risco, como traduz a ausência dela na condução da gestão do País, das unidades federativas e dos sistemas de ensino.

Segundo matéria do jornal A Tarde, no evento de Salvador, o governador falou das suas motivações para retirada do comando das escolas de civis e transferências para a gestão militar. O então governador declarou: 
Fui num evento e tinha um grupo de professores radicais da extrema esquerda me xingando. Eu disse: tenho um remedinho pra vocês. Colégio Militar e Organização Social. Identifiquei as oito escolas desses professores. Preparei um projeto de lei e em seguida militarizei essas oito escolas. O Brasil está precisando de 'nego' que tenha coragem de enfrentar².

A lógica coronelista daquele que faz as suas próprias leis, mesmo governando uma unidade federada em um Estado Democrático de Direito, parece não ter limites. Perillo, segundo a matéria, disse ter descoberto que o Sindicato dos Professores estava descontando um percentual dos servidores para a entidade, sem autorização. E que esses recursos eram usados para custear propaganda contra o governo na TV. A questão foi resolvida não com a negociação entre direção sindical e sindicalizados, mas sim por ele. "Estavam arrecadando R\$ 750 mil por mês. Mandei cortar", pois não pretende "fazer graça com esse pessoal que não está preocupado em melhorar a educação" ${ }^{3}$ E continua

Não consigo ver a educação avançando com sindicatos agressivos e essa coisa de professor pedir licença para tudo a qualquer hora. Vou conseguir chegar a uma melhoria na medida que o mau professor ou professor relapso, ou professor que não cumpre suas metas, possam ser desligados. Só no fato de a gente quebrar a espinha da contratação, de definir metas claras, será uma outra coisa4.

Nesse caso, nos parece que o anseio persecutório do governador encontrou eco no regimento dos colégios militares. No Artigo 128, o documento assevera, dentre outras questões, a vedação:

[...] pregar doutrinas contrárias aos interesses nacionais, influenciando os demais membros da comunidade à tomada de atitude indisciplinada, irreverente ou de agitação, ainda que de forma dissimulada; descumprir, negligenciar ou incentivar o não cumprimento de qualquer ordem emitida porautoridade competente ou das disposições legais; praticar atos que perturbem a ordem, a moral e os bons costumes ou importem em desacato às leis e às autoridades constituídas; promover ou participar de movimento de hostilidade ou desrespeito ao CPMG ou a qualquer autoridade constituída; falar, escrever ou publicar artigos ou dar entrevistas, ou ainda divulgar assunto que envolva, direta ou indiretamente, o nome do CPMG e da comunidade escolar, em qualquer época, sem que para isso esteja autorizado pelo Comandante e Diretor (Art. 128 e incisos).

Indo além do eufemismo das palavras e terminologias utilizadas no documento, nos parece que o que se almeja é coibir a ação organizada da comunidade escolar em relação às possíveis arbitrariedades que possam ser desencadeadas nas escola militarizadas, já que o próprio regimento admite "medidas preventivas e repressivas de atos de indisciplina individual e coletiva dos discentes" (Art.57, Inc.II).

A matéria dos jornalistas Patrik Camporez e Daneil Merenco, veiculada pela revista Época (23/07/2018), aponta que, além das 46 escolas já sob o comando da polícia Militar, 


\begin{abstract}
Atualmente, outras 39 escolas de Goiás estão em processo de militarização - e o modelo seguido pelo estado está se espalhando rapidamente pelo país. Um levantamento feito por ÉPOCA descobriu que, de 2013 a 2018, o número de escolas estaduais geridas pela Polícia Militar saltou de 39 para 122 em 14 estados da Federação - um aumento de 212\%. Em 2019, outras 70 escolas deverão ser colocadas sob a gestão de militares nesses estados. O fenômeno se reproduz por todo o país, mas com mais intensidade nos estados do Norte e do Centro-Oeste. Amazonas já conta com 15 escolas administradas pela PM. Mato Grosso pretende criar cinco escolas da PM no segundo semestre. Em Roraima, das 382 escolas da rede estadual de ensino, 18 unidades foram militarizadas, totalizando 20 mil alunos sob jurisdição militar. ${ }^{5}$
\end{abstract}

A LDB prevê a articulação da escola com as famílias e a comunidade e participação destas em conselhos escolares, mas no caso da gestão militarizada, impera a hierarquia e os pais são chamados às escolas para tratar das sanções disciplinares dos seus filhos. $\mathrm{O}$ conselho escolar é composto majoritariamente pelos policiais militares e seu regimento definido pelo alto comando da PM, baseado na filosofia militar - e que deverá ser cumprido à risca por educandos, educadores, pais e comunidade.

Uma breve análise dos princípios que regem a educação escolar nos colégios militarizados e os postos na LDB oferece a dimensão de quais são os fins e objetivos que permeiam a concepção de educação almejada. 


\section{Quadro 1: Comparativo entre os princípios postos na LDB e do regimento interno do CPMG}

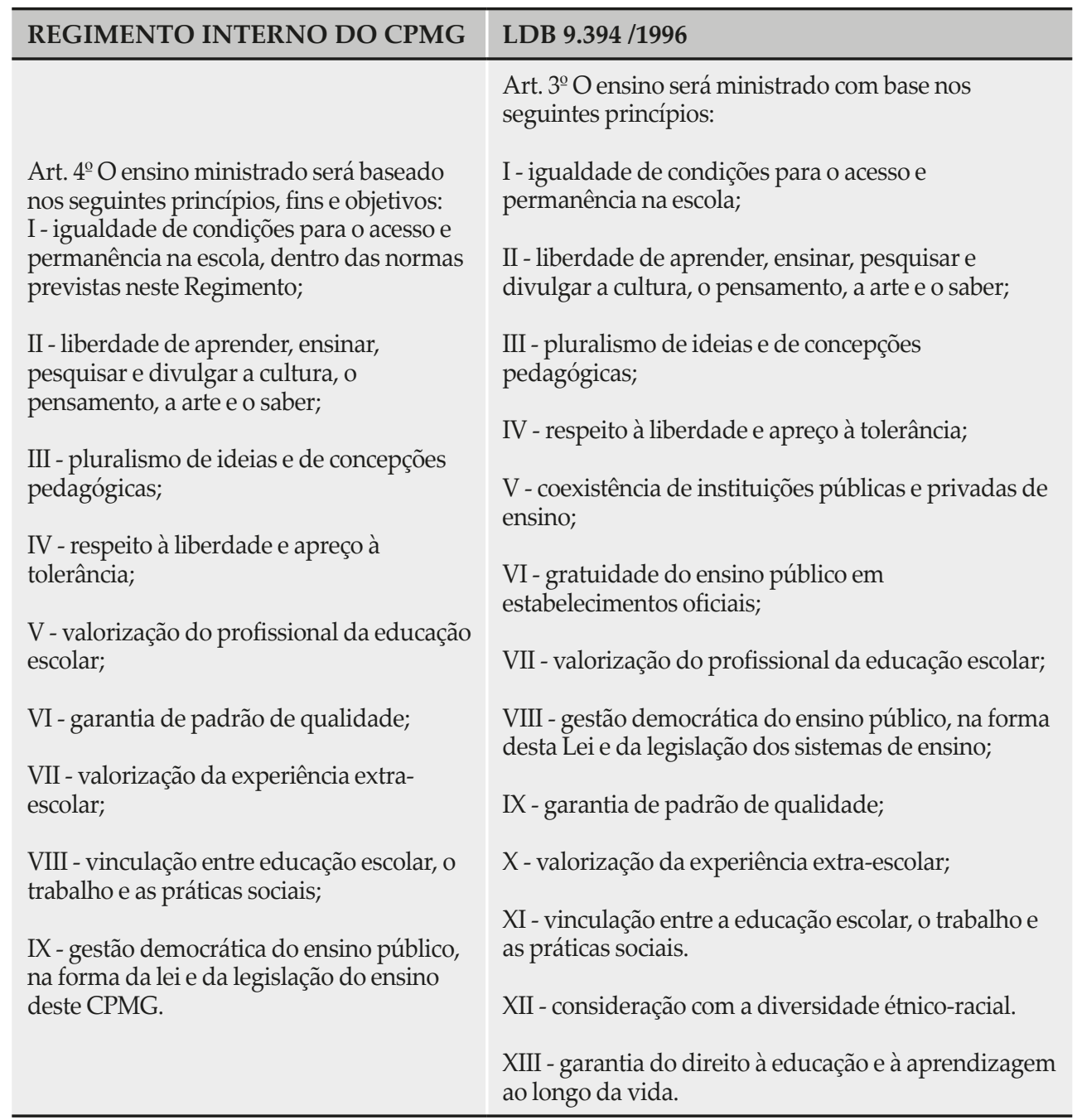

Fonte: Regimento Interno do CPGM e LDB. Elaboração dos autores

Os princípios presentes na LDB ratificam os preceitos constitucionais e devem ser seguidos pelos sistemas de ensino, especialmente os sistemas públicos, e são basilares para o desenvolvimento de projetos educativos que contribuam na formação de sujeitos livres e solidários. Tendo em vista que os colégios militarizados são escolas desses sistemas, a Lei deveria se aplicar a elas também. No entanto, o Regimento Interno desses colégios faz adaptação desses princípios de modo a atender a filosofia militar e não os princípios da educação nacional. 
O regimento interno do CMPG exclui alguns princípios e adapta outros. O princípio da igualdade de condições para o acesso e permanência na escola permanece, desde que sejam seguidas as normas militarescas previstas no Regimento. $\mathrm{O}$ mesmo se repete com a gestão democrática do ensino público, que se mantém no documento como princípio, desde que siga as normas estabelecidas no regimento do CPMG, que são normas militares. E assim sendo, torna-se um princípio figurativo. Nessa lógica, a gratuidade do ensino público em estabelecimentos oficiais e a diversidade étnico-racial foram excluídos do regimento, afinal os colégios militarizados cobram taxas, travestidas de "contribuição voluntária", e a única diversidade permitida é a das patentes e a hierarquia militar.

Nessas escolas os diretores não são profissionais da educação, eleitos pela comunidade escolar, mas um tenente-coronel, designado pelo alto comando da PM cuja sala, os adornos e os métodos pedagógicos e de gestão traduzem quais os princípios que regem o quartel-escola. Os pais não são convidados para participar dos conselhos escolares, afinal, não há de fato conselhos, há hierarquia e obediência. Assim, eles são chamados para tomar ciência das sanções disciplinares que seus filhos recebem, caso fujam das rígidas regras do quartel. A revista Época descreve com detalhes a sala do diretor da Escola Estadual Waldemar Mundim, uma das unidades escolares sob a gestão da Polícia Militar de Goiás.

A sala do tenente-coronel é adornada por 30 cabeças de caveira de plástico e metal. É nesse espaço que ele recebe os pais para tratar das sanções aplicadas aos alunos. Nos dias em que a reportagem de EPOCA visitou o colégio, o comandante diretor exibia com orgulho sua nova conquista para reforçar a segurança da escola, que já era patrulhada internamente por militares ostensivamente armados: um recém-implantado sistema de vídeomonitoramento, que instalou uma câmera em cada sala de aula a fim de controlar os alunos em tempo integral. "Havia muito furto de pulseira, relógio, celular", disse Guimarães. "Colocamos a câmera para combater esses furtos". 6

O irônico é que a justificativa para repassar as escolas para a gestão da Polícia Militar é a diminuição da violência. As escolas selecionadas estão localizadas em sua maioria na periferia, onde há altos índices de homicídios, ou seja, nos locais em que a polícia não desempenha seu papel constitucional de garantir a ordem pública e a segurança. Se o objetivo é ter um local seguro para educadores e educandos desenvolverem seu trabalho, parece-nos que o posto de comando do tenente-coronel não deveria ser a escola.

Se a polícia é preparada para garantir segurança e não tem demostrado competência no desempenho de sua função, não é possível acreditar que ela consiga ser competente em algo para o qual ela não foi criada e que é, na sua essência, diametralmente oposta ao que se propõe. Afinal, como assinalou Teixeira, a educação no seu verdadeiro sentido é o meio pelo qual o homem, todos os homens e todas as mulheres aprendem a ser livres e capazes. 


\section{Escola sem partido e "militarização" do trabalho docente}

O famigerado movimento "Escola sem partido" (ESP) tem ocupado os pensamentos e ações de diversos educadores pelo País afora. Trata-se de um movimento orquestrado por setores conservadores da sociedade civil que buscam "disciplinar" o trabalho docente, sobretudo, nas escolas de educação básica pública.

Espraiados pelo movimento conservador que ganhou folego após o golpe jurídico, midiático e parlamentar de 2016, o ESP ganha destaque e simpatia nos setores mais atrasados do Congresso Nacional e dos legislativos estaduais e municipais. Idealizado pelo procurador do estado de São Paulo, Miguel Nagib, o ESP propõe uma verdadeira mordaça aos educadores, com o argumento de que a função da escola é somente ensinar, diferente, portanto, daquilo que manda nossa Constituição e a Lei de Diretrizes e Bases da Educação Nacional, que deixam clara a função social da escolas e suas finalidades: pleno desenvolvimento da pessoa; formação para cidadania e; preparação para o trabalho, permeados pelos princípios da liberdade de aprender ensinar e da pluralidade das ideias e concepções pedagógicas.

São vários os projetos de lei que tramitam pelas casas legislativas do País, porém, para além dos fundamentos cerceadores do trabalho docente, há no mínimo quatro elementos que lhes dão certa unicidade: i) são propostos por parlamentares de partidos conservadores; ii) atacam a educação e a escola pública; iii) detêm apoio do empresariado educacional e dos detentores dos meios de produção; iv) partem do pressuposto de que os professores e as professoras fazem proselitismo político-partidário e cerceiam o direto de aprender dos estudantes.

Nesse sentido, o ESP dever ser analisado para além de sua aparência fenomênica - via discurso da liberdade de ensinar do professor e do direito de aprender do aluno. É preciso desvelar o que está oculto no projeto e quais são, de fato, suas intencionalidades. Sua essência. Nos ajuda nessa reflexão não isolar o ESP das demais iniciativas que ganharam força no período que se abriu após o golpe de 2016 e da dinâmica mais geral do processo de reconfiguração do capital internacional e nacional e suas repercussões na educação.

Gramsci (1991) nos alerta que toda relação de hegemonia é uma relação pedagógica e essa relação será desenvolvida pelos grupos dominantes na direção do Estado, imputando a este uma condição educadora que intenta obter (falsos) consensos a favor dos interesses de classe a qual está submetido. Nesse processo, as classes dominantes formam seus intelectuais orgânicos para que sejam caudatários das intencionalidades do capital. Por sua vez, esses intelectuais constroem, difundem e organizam um determinado tipo de sociabilidade que precisa ganhar terreno, sobretudo, na superestrutura a fim de formar cidadãos de novo tipo que consentem com uma realidade estranhada do seu fazer cotidiano. Aqui há o encontro dos processos de militarização e da "Escola sem partido"; ambos buscam um novo tipo de intelectual, que consente com a estrutura 
econômico-social desumana e desigual e com a ideologia da coesão social de caráter autoritário e conciliatório.

Nesses termos, escola e educação são fenômenos essencialmente políticos. Não há neutralidade no ato de ensinar e educar. Todas as teorias de ensino-aprendizagem são permeadas de metodologias e métodos que respondem à determinadas concepções de homem, de sociedade e de mundo. O que há de fato, nesse discurso de suposta neutralidade que empreende o ESP é o absolutismo, em última instância, a negação do diferente, a intolerância com o diverso. Não por acaso, o projeto em discussão na Comissão Especial$^{7}$ da Câmara dos Deputados, fruto de um parecer do deputado Flavio Augusto da Silva, conhecido como Flavinho, do Partido Social Cristão (PSC/SP), ao Projeto de Lei no 7.180, de 2014, de autoria do deputado Erivelton Santana, também do PSC, mas do Estado da Bahia, e outros projetos apensados vedam, por exemplo, o que se chama de "ideologia de gênero", que classificam como:

[..] uma concepção extremamente controversa, defendida por uma minoria de intelectuais e ativistas políticos, como Simone de Beauvoir, Michael Foucault, Judith Butler e Shulamith Firestone, segundo a qual o "gênero" é um construto social dinâmico e suscetível de mudanças, não uma imposição biológica. Para eles, a palavra "gênero" não é mais sinônimo de "sexo", como na perspectiva convencional; mas refere-se a um papel social que pode ser construído - e desconstruído - conforme a vontade do indivíduo (SILVA, 2018, p. 17).

Diante de tantos ataques ao trabalho docente que constam do relatório do referido PL, este talvez seja um dos mais intensos, isso porque desconsidera pesquisas científicas, mundialmente reconhecidas, que tratam da temática e representam o conhecimento e reconhecimento de uma realidade concreta vivida pelas sociedades e seus sujeitos. Ao negar o debate sobre gênero nas escolas e as referências científicas em torno da temática, o parlamentar deixa claro o que se quer com o Projeto de Lei: proibir o contraditório, ou melhor, como diz o regimento dos colégios militares: proibir "doutrinas contrárias aos interesses nacionais", que, na perspectiva do parlamentar, seria a "perspectiva convencional".

Concordamos com a carta do "Movimento Educação Democrática" quando afirma que a vedação ao debate de genêro nas escolas,

\footnotetext{
"mostra-se absurdo por censurar todo um campo científico que se apoia sobre "gênero" enquanto uma categoria de análise, além de censurar também debates essenciais para uma percepção mais aprofundada dos mecanismos de reprodução das desigualdades sociais no contexto escolar e na sua contestação" (Movimento Educação Democrática, 2018, s/p).
}

Os PL da Escola sem Partido localizam-se em um processo maior das contra-reformas educacionais empreendidas pelo Governo Temer. Não por acaso foram a PEC do Teto dos Gastos e a Reforma do Ensino Médio as primeiras iniciativas do governo golpista. Isso porque retirar recursos da educação e saúde é de interesse do capital em duas 
direções: a primeira corresponde à disputa e expropriação do fundo público; a segunda na mercantilização e privatização, atacando o direito universal à educação pública. Por outro lado, retomar as teses do Capital Humano, via ensino médio, é resgatar o aprofundamento da dualidade estrutural nessa etapa da educação básica, fortalecendo um ensino para ricos e outro para pobres.

As duas iniciativas corroboram o processo de formação de cidadãos de novo tipo, devidamente instruídos e treinados para atender às demandas do mercado de trabalho e das novas exigências do processo de reestruturação produtiva do capital. Coadunam com elas, a "liberdade de ensinar" defendida pelos arautos do ESP que tem a ver com essa sociabilidade capitalista que intenta estudantes e professores apaziguados, sem opinião, corpos sem mente, desumanizados, generalizados, expropriados dos determinantes que lhes dão sentido humano. Nos parece que há uma intima ligação entre os processos de militarização de escolas e o projeto ESP. Na realidade, militarizar escolas é materializar tal projeto.

Nesses termos a essência da "Escola sem partido" parte da aparente defesa da liberdade de ensinar para percorrer o caminho do pensamento único, da escola de partido único. A "liberdade de ensinar" refere-se, apenas, ao ensino instrumental, comprometido com os determinantes do capital, do seu empresariado educacional local e global. Uma educação competente, eficiente e eficaz segundo os parâmetros privados, meritocráticos, sem função social e coletiva.

Não por acaso, ao tentar justificar a suposta importância do projeto, seu relator, por meio de contorcionismos linguísticos, que, na realidade são estratégias ideológicas, tenta, sem sucesso, defender o Projeto e, ao mesmo tempo, a liberdade de cátedra. Segundoo parlamentar:

[...] Liberdade de cátedra, portanto, não é uma licença estatal para se fazer o que bem quiser, pois se assim o fosse violaria frontalmente o direito do aluno de aprender. É óbvio que a Constituição declara livre a "manifestação do pensamento" no seu art. $5^{\circ}$, inciso IV. Afirma também que "é livre a expressão da atividade intelectual, artística, científica e de comunicação, independentemente de censura ou licença", conforme expresso no art. $5^{\circ}$, inciso IX. Contudo, isso não significa que não haja limites à atividade docente. Tal autonomia não confere liberdade absoluta, seja ao professor da rede pública, seja ao docente da rede privada. O professor não se acha acima da lei. A autonomia de que goza acha-se restrita ao exercício de suas atribuições e sofre limites por um círculo maior de legalidade (SILVA, 2018, p. 6).

O excerto mostra a dificuldade do relator em justificar a intencionalidade do projeto em cercear o trabalho docente, busca amparo na Constituição Federal , porém, contraditório com o que o projeto defende. Além disso, parte da premissa que os docentes "ensinam o que querem" o "que concordam". Busca impor limites, seus limites, os limites de sua perspectiva político-partidária, já que ele próprio faz parte de uma agremiação que reivindica o "conservadorismo" entendido como "respeito à tradição" e tem em seus fundamentos a defesa da "família tradicional, a liberdade econômica, o Estado mínimo" (PSC, s/d). 
Substitutivo apresentado pelo parlamentar sintetizado nos dizeres dos cartazes, que deverão ser afixados nas escolas públicas e privadas País:

Deveres do professor

I- O professor não se aproveitará da audiência cativa dos alunos, com o objetivo de cooptá-los para nenhuma corrente política,ideológica ou partidária;

II - O professor não favorecerá nem prejudicará os alunos em razão de suas convicções políticas, ideológicas, morais ou religiosas;

III - O professor não fará propaganda político-partidária em sala de aula nem incitará seus alunos a participar de manifestações, atos públicos e passeatas;

IV - Ao tratar de questões políticas, socioculturais e econômicas, o professor apresentará aos alunos, de forma justa - isto é, com a mesma profundidade e seriedade -, as principais versões, teorias, opiniões e perspectivas concorrentes a respeito;

V - O professor respeitará o direito dos pais a que seus filhos recebam a educação moral que esteja de acordo com suas próprias convicções;

VI-O professor não permitirá que os direitos assegurados nos itens anteriores sejam violados pela ação de terceiros, dentro da sala de aula (SILVA, 2018, p. 27).

Embora ainda não aprovados no Congresso Nacional, os parâmetros da ESP já gozam de ampla aceitação nos setores conservadores, a exemplo da reação aos debates sobre gênero nos planos nacional, estaduais e municipais da educação. Nos processos de militarização das escolas públicas. Ou ainda no debate sobre o material da campanha "Escola sem Homofobia".

Como se não bastassem esses ataques ao caráter público, laico e gratuito da educação e à sua função social, coletiva e solidária, o Governo Temer intenta um novo currículo para a educação básica pública no qual o slogan das competências de aprendizagem assumem centralidade, materializando, portanto, as diretrizes do ESP. Mesmo que à primeira vista essa simbiose esteja velada, a análise mais aprofundada da Base Nacional Comum Curricular (BNCC) defendida pelo Ministério da Educação caminha para fixar aos educadores conteúdos estáticos que engessarão ainda mais o trabalho docente, impondo aos profissionais do magistério uma cartilha linear, a exemplo do que já acontece em diversos sistemas municipais de ensino que se utilizam de métodos de apostilamento de conteúdos, prática que tem origem nas instituições privadas.

Há um projeto hegemônico-conservador que caminha a passos largos na sociedade brasileira. O golpe acentuou essa marcha e, na educação, esse projeto tem se materializado de maneira mais acelerada do que em outras áreas sociais. Estamos lidando com intelectuais orgânicos ${ }^{8}$ que reconhecem o papel da educação na formação para cidadania, portanto, faz parte da sociabilidade do capital, uma educação desnutrida de sentidos.

Tanto é assim que o atual governo rompeu com todas as conquistas democráticas mesmo que contraditórias - do último período, a exemplo do protagonismo da sociedade 
civil organizada na construção da Conferência Nacional de Educação, na participação no Fórum Nacional de Educação e do monitoramento e implementação do Plano Nacional de Educação (2014-2024). Ação autoritária que levou diversas entidades científicas, sindicais e sociais do movimento social de educação a construir o Fórum Nacional Popular de Educação e organizar uma vitoriosa Conferência Nacional Popular de Educação.

É importante salientar, portanto, que o movimento "Escola sem Partido" não é apenas uma manifestação isolada do conservadorismo que assombra a sociedade brasileira. Ele faz parte de um todo, que é muito organizado e concatena suas ações, ora via representantes na sociedade civil, ora na sociedade política ${ }^{9}$. Por um lado, criam manifestações ideológicas para a construção de (falsos) consensos, por outro, materializam ações que enfraquecem o financiamento público da educação e limitam o trabalho docente.

Se é verdade que todos somos filósofos e que cabe a nós não só interpretar o mundo mas, decididamente, transformá-lo, precisamos continuar mobilizados para enfrentar esta e outras atrocidades que atentam contra a educação pública, gratuita, democrática, laica e com qualidade socialmente referenciada.

\section{Considerações finais}

Este texto buscou apontar que o processo de militarização das escolas públicas, assim como o movimento/projeto "Escola Sem Partido" em curso no Brasil ameaçam direitos constitucionais fundamentais e, em última instância, o Estado Democrático de Direito e seus fundamentos. Esses processos põem em risco a formação para a cidadania, a dignidade da pessoa humana, o pluralismo político e a construção de uma sociedade livre, justa e solidária.

Tanto o movimento ESP como a militarização das escolas públicas são projetos de cunho conservador que objetivam a destruição dos direitos sociais, dentre eles o direito à educação de qualidade socialmente referenciada e seus princípios basilares. Esses projetos são peças de um projeto hegemônico, composto de outras que vêm sendo movimentadas no cenário mundial e brasileiro, para a manutenção da hegemonia do capital por meio de uma formação destituída de interesse socialmente referenciado.

Recebido em: 15/08/2018 e aprovado em: 17/08/2018 


\section{Notas}

1 http://atarde.uol.com.br/politica/noticias/1727346-goias-vai-terceirizar-a-educacao-apos-experiencia-na-saude.

2 http://atarde.uol.com.br/politica/noticias/1727346-goias-vai-terceirizar-a-educacao-apos-experiencia-na-saude.

3 http://atarde.uol.com.br/politica/noticias/1727346-goias-vai-terceirizar-a-educacao-apos-experiencia-na-saude.

4 http://atarde.uol.com.br/politica/noticias/1727346-goias-vai-terceirizar-a-educacao-apos-experiencia-na-saude.

5 https:/epoca.globo.com/numero-de-escolas-publicas-militarizadas-no-pais-cresce-sob-pretexto-de-enquadrar-os-alunos-22904768.

6 https://epoca.globo.com/numero-de-escolas-publicas-militarizadas-no-pais-cresce-sob-pretexto-de-enquadrar-os-alunos-22904768.

7 No dia 04 de Outrubro de 2016, o presidente da Câmara dos Deputados, Rodrigo Maia(DEM/RJ), criou a Comissão Especial para proferir parecer sobre os projetos que versam sobre a temática. A Comissão é presidida pelo deputado Marcos Rogério da Silva Brito (DEM/RO).

8 De acordo com Gramsci (1991).

9 Para o leitor que queira se aprofundar nesse tema sugerimos a leitura de duas coletâneas recentes. A primeira organizada pela Ação Educativa: "A ideologia do movimento Escola Sem Partido - 20 autores desmontam o discurso". A segunda organizada pelo professor Gaudêncio Frigotto: "Escola "sem" partido: esfinge que ameaça a educação e a sociedade brasileira".

\section{Referências}

BRASIL. Constituição da República Federativa do Brasil. Brasília, DF: Senado Federal, 1988.

. Lei no 9.394, de 20 de dezembro de 1996. Estabelece as diretrizes e bases da educação nacional.

GOIÁS. Secretaria de Segurança Pública. Regimento Interno do Colégio da Polícia Militar Do Estado De Goiás. Disponível em: <https://www.cpmganapolis.net/wp-content/uploads/2015/05/regimento_ interno.pdf>. Acesso em: jul. 2018.

GRAMSCI, A. Os intelectuais e a organização da cultura. Tradução de Carlos Nelson Coutinho. $8^{a}$ edição. Rio de Janeiro: Civilização Brasileira, 1991.

MOVIMENTO EDUCAÇÃO DEMOCRÁTICA. Carta aberta em defesa da Educaçào democrática: contra projetos de censura à educação nacional. Disponível em: https:// professorescontraoescolasempartido.wordpress.com/2018/07/05/carta-aberta-em-defesa-da-educacaodemocratica-contra-projetos-de-censura-a-educacao-nacional/. Acesso em: 15 ago.2018.

SILVA, F. A. Parecer do Relator pela constitucionalidade, juridicidade e técnica legislativa; e, no mérito, pela aprovação deste, do PL 7181/2014, do PL 867/2015, do PL 1859/2015, do PL 8933/2017, do PL 9957/2018, do PL 6005/2016, e do PL 5487/2016, apensados, com substitutivo. Disponível em: http://www.camara.gov.br/proposicoesWeb/prop_ mostrarintegra;jsessionid=C484F2745AF0933C6793FB8BB3D39D4B.proposicoesWebExterno2?codteor= 1657686\&filename=Tramitacao-PL+7180/2014. Acesso em: 15 ago. 2018.

TEIXEIRA, Anísio. Autonomia para a Educação. In: ROCHA, João Augusto de Lima (Org.). Anísio em movimento. Brasília: Senado Federal/Conselho Editorial, 2002. 